\title{
OLD-AGE SECURITY ABROAD: THE BACKGROUND OF TITLES II AND VIII OF THE SOCIAL SECURITY ACT
}

\author{
Barbara Nachtrieb Armstrong*
}

More than a hundred years ago Great Britain recognized in specific legislation that provision for old age through individual saving presented difficulties. In a statute enacted in $1833,{ }^{1}$ the British Parliament initiated a policy of offering old-age annuities through the National Debt Commissioner to persons who desired to make systematic preparation for income during their retirement period. Belgium, France and Italy ${ }^{2}$ enacted similar laws in the fifties. These measures had little practical result as the opportunities for purchase of old-age annuities secured by the public credit were not taken advantage of by appreciable numbers.

- More effective, of course, were the compulsory annuity arrangements set up in the latter half of the nineteenth century by various European countries ${ }^{3}$ for workers in selected industries, such as mining, navigation and later, railroading. In the case of mining, these schemes were but public organization on a compulsory basis of provident funds which provided accident and sickness insurance as well as old age protection. These funds dated back to the early middle ages and had always been, by virtue of custom more effective than any formal law, a required part of organized community life in mining villages. ${ }^{4}$

In point of time of origin the French Seamen's Invalidity and Old Age Insurance Fund commands special attention. It was established in $1673^{\circ}$ and, barring occasional interruptions during periods of violent political change, continuously functioned thereafter. It was moreover not only the first compulsory insurance institution created by national law to provide old-age security but also in all probability the first

- A.B. 1913; J.D. 1915; Ph.D. 192r, University of California. Professor of Law, University of California. Consultant (on Unemployment and Old-Age Insurance) to Committee on Economic Security, I934; Exccutive Secretary, California Social Insurance Commission, 1915-1919; Member of Faculty-of-Economics and Law Departments, University of California, 1919 to 1926; Member of Law Department since 1926. Author of Insturing the Essentials (Macmillan Company, 1932). Contributor to legal periodicals, Encyclopedia of Social Sciences, Survey, Political Science Annals, National Municipal Review, etc.

${ }_{3} \& 4$ Wm. IV, c. 14 (1833).

For a discussion of these measures, see U. S. COMM'R of LABOR, 24TH ANN. REP. (1909) 83, 503, 863.

II. $413,524,532,881,889,1396-99,2001-2004$.

' See U. S. Comm'r of Labor, 4 th Spec. Rep. (1893).

"For the text of this act as originally enacted, see I9 Isambert, RecueIl des ANCiennes Lois FranCAISES (I822-33) II 8 . 
instance of any branch of social insurance being put on a statutory compulsory basis. Widespread legislative interest, however, in systematic provision of annuities even for special groups of workers dates well along in the late nineteenth century.

The first compulsory annuity scheme applying to industrial workers was set up in $1889^{6}$ by the usual pioneering social insurance country-Germany. As in the case of the earlier sickness and industrial accident insurance provision, the main features of the German system were patterned after those of the ancient mining funds. Annuities were payable in the case of either invalidity or old age. The former was defined as loss of more than two-thirds earning capacity and the latter as arrival at the age of seventy. ${ }^{7}$ The insured workers and the employers were required to share the premiums needed for financing the benefits. Premiums varied with the wage level of the worker and annuities were adjusted both to the size and number of premiums paid. In addition, the government bore part of the financial burden of the scheme by granting an annual supplement to each annuity paid. ${ }^{8}$

This German program rested on the simple assumption that, since most workers did not, or could not, accumulate surplus enough to maintain them in their old age, the building of an annuity fund by systematic contributions from wage earners and their employers should be required. Thus not only would the individual worker be assured a "backlog" of income towards the end of his life but also the community would be protected from a serious old-age dependency problem.

Shortly after the establishing of this compulsory annuity program by Germany, other countries attacked the problem of old-age security in two other ways. One, like the German, was a "contributory annuity" program to provide pensions payable as a right and not conditioned on need. It involved, however, the inducing rather than the compelling of contributions. Belgium (I89r), France (1895), Italy (1898), Spain (Ig08) experimented with plans ${ }^{2}$ involving public subsidies to individual annuities voluntarily purchased from the government. The subsidies offered in the Belgian and Italian schemes constituted one-half or more of the total cost of the annuities provided, while those of France and Spain were markedly smaller and the effectiveness of the subsidies in inducing purchase of annuities varied, of course, directly with their size. ${ }^{10}$ Aside from the inevitable objection to their cost, the chief adverse criticism directed at these "subsidy" schemes was that small landowners and the lower bourgeoisie constituted the bulk of the annuitants, whereas the industrial workers who were most apt to arrive at old age penniless were not reached in substantial numbers.

'For a full description of the original act, see U. S. CoMm'r of LABOR, 24TH ANN. REP. 1356-I 404. For a complete translation of the Igr I Revised Social Insurance Code, see U. S. BUR. op LAbor Stat. BuLl. 96 (IgII) (Employes' Insurance); $c f$. BuLL. 107 (IgI2). Insurance of manuals and non-manuals v. provided in two separate systems.

${ }^{7}$ U. S. Bur. of Labor Stat. Bull. 96 (1911) Articles 1255-1257.

Id., Articles 1387-1391.

'U. S. COMM'R OF LABOR, 24TH ANN. REP. 503-504, 510-511, 836-837, 858-861, 1875-1885, 2362, 2372.

${ }^{10} \mathrm{Id}$., pp. 505, 861, 870-871, 1894; also Annuario Statistico Italieno AnN. 1915, pp. 27, 279. 
Much more significant in growth than the voluntary subsidized technique, was the other type of old-age provision, involving gratuitous pensions. This became for twenty years or so a serious competitor to the German compulsory contributory annuity plan. Denmark was the pioneer in this instance, establishing in $189 I^{11}$ a system of government money grants for meritorious citizens who arrived at old age without a competence. These grants or "pensions" were completely differentiated from poor relief and were intended to carry no stigma. ${ }^{12}$ The philosophy underlying this type of provision was in marked contrast with the pragmatic assumptions on which was rested the contributory insurance scheme adopted by Germany. The latter merely accepted, without moralizing, the fact of wide prevalence of old-age dependency, the practical impossibility of relying upon individual effort for the control of such dependency and the effectiveness of a socially-controlled compulsory contributory annuity plan as a method of attack upon the problem.

The Danish pension scheme, on the other hand, was based upon the conviction that those who had been good citizens and independent self-respecting workers had made a valuable contribution to their community and were entitled in return to help from the public funds, if they could not maintain themselves in old age. In short, the Danish program was directed at the "worthy" aged who were in distress, with perhaps the belief that the incentive of old-age security would induce the citizenry to eschew undeserving ways of living. The grant or pension was adjusted to the need of the pensioner, the government offer being in the nature of surety to guarantee the deserving aged citizen's income should his own means fail. ${ }^{13}$ The so-called "moral" qualifications were numerous and severe and reflected the conviction of the period that only the undeserving and undesirables had to seek public aid during their vigorous working years. The applicant had to prove not only that he had neither been convicted of crime (unless pardoned), nor been guilty of "vagrancy, mendicancy or living in such a way as to offend public morality" but also that he had not within ten years received poor relief assistance. ${ }^{14}$

The communal authorities were allowed to determine the amount of the pension in each case and were reimbursed by the Danish Exchequer to the extent of one-half of their expenditures for old-age support. ${ }^{15}$ Dependency upon children was not forced, although actual provision willingly made for parents was treated as income in judging the applicant's need. ${ }^{16}$

.Denmark's first disciple was a British colony in the antipodes, New Zealand. The basic principles of the Danish plan were accepted in the New Zealand scheme

"iv. S. Cóma'r of LABOR, 24 TH ANN. Rep., 624.

${ }^{12}$ Id., 623, 633. The title of the act read "Law of April $189 \mathrm{I}$ concerning old age support for the worthy poor, aside from poor relief." Civil rights were lost with the acceptance of poor relief but not, however, for drawing of pensions. Different offices administered the two kinds of assistance. For a digest of the act, see ANNuAre de Legislation Etrangere (I891) 787-788.

23 U. S. COMM'R OF LABOR, 24 TH ANn. Rep. 626.

${ }^{16} 1 d .625$.

${ }^{25} I d .632$.

${ }^{18} 1 d .628-629$. 
which was legislated in $1898 .{ }^{17}$ Criminal offenders, family deserters and other persons of bad moral character were disqualified. The size of the pension, however, while adjusted to the applicant's need as in Denmark, was dictated by the terms of the statute in the New Zealand scheme rather than left to the discretion of the administrative authorities. Two Australian states enacted similar measures in $190 \mathbf{r}^{18}$ which functioned until a federal pension act, effective in all the Australian states was passed by the Commonwealth of Australia in $1908 .{ }^{19}$ France meanwhile had enacted a gratuitous pension measure in $1905 .^{20}$

The acceptance of this type of old-age security, moreover, by Great Britain in her enactment of $1908^{21}$ which provided non-contributory pensions for the "aged and deserving poor" added a nation of major industrial importance. This not only affected the choice of old-age security provision in Canada, ${ }^{22}$ Newfoundland ${ }^{28}$ and South Africa, ${ }^{24}$ but also markedly influenced thought in this country with respect to old-age dependency problems.

Experience revealed certain significant weaknesses in this, the gratuitous pension, type of old-age security provision. First, and perhaps most important, by adjusting the pension to the needs of the pensioner, it put a premium not upon self-help but upon the opposite. The more the applicant had, the less he received from the government and vice versa. Thus the scheme was basically at war with the fundamental principle of contemporary life, which demands that each individual make every effort to accumulate for his own self-maintenance. Attempts were made to meet this difficulty by amendments which exempted certain amounts of savings or income in pension computations. Thus after less than a decade of experience the Danish Act was amended to permit income up to roo kroner per year to be disregarded in judging the applicant's need for a pension. ${ }^{25}$ This provision was periodically revised and liberalized. Similar "exemptions" of stipulated sums were included in other pension schemes and they too were liberalized by subsequent amendments, in an endeavor to meet the generally expressed objection that thriftlessness was promoted by the gratuitous pension plan. ${ }^{26}$

A second important limitation of the gratuitous pension plan revealed by experience, was the practical difficulty of enforcing its moral qualification clauses. Administrators sitting in judgment on the aged and dependent applicants found that the theory of aid only to the deserving and worthy, however justified on moral grounds, was a distasteful one to put into practice. Strong public sentiment developed against

\footnotetext{
${ }^{27}$ New Zealand Stat. 1898 , No. I4.

${ }^{13} \mathrm{New}$ South Wales and Victoria.

10 Australia Stat. 1908, No. ry.

20 This was frankly aid for the indigent (institutional and non-institutional), not "reward for the worthy." For a description of its terms, see U. S. CoMm'R of LABoR, 24TH ANN. Rer. 919-923.

${ }^{21} 7$ Ed. VII, c. 40 (1908).

${ }^{22}$ Canada Stat. 1927, c. 156.

${ }_{23}^{2}$ Newfoundland Stat. I9II, c. XXIX; Cons. Star. (Igr6) c. 74.

${ }^{2}$ Union of South Africa Stat. 1928, No. $22 .{ }_{25}$ U. S. COMM'r or LABor, 24 ta ANN. Rep. 626.

${ }^{20}$ The increases were, of course, partly in deference to changes in purchasing power of money. See New Zealand Stat. 1913, No. 10, §5; 1924, No. 34, 54 ; Australia Stat.'1908, No. 17, 524; 1916, No. 32, $\$ 3$ (a); Great Britain, I \& 2 Geo. V, c. I6, \$2 (c) (rgri); 9 \& 10 Geo. V, c. ro2, \$4 (1919); I4 \& 15 Geo. V, c. 33, \$r (I924).
} 
the penalizing of people at a time when they were old and helpless. This was reflected by the provisions of the later measures and amendments which repeatedly modified and softened the "moral qualifications" requirement." In result the schemes began to lose their original complexion of special provision for the old age of meritorious citizens and to take on an aspect of systematic general provision for necessitous old persons. The burden to the public funds mounted steadily as the percentage of eligible population granted pensions increased year by year. These facts, together with the distaste which the self-respecting old person felt at having to prove need by submitting to an investigation which inevitably smacked of poor relief procedure, combined to develop a sentiment against this method of attacking the problem of old-age security.

The insurance or annuity technique offered several practical advantages as compared with the gratuitous pension plan. By requiring systematic contributions during working years, it eased the burden on the general tax receipts. By producing an annuity to which the insured worker was entitled as a right, it removed the pension from any possible connection with poor relief. Since the wage earners were required to participate in the scheme, whether they were deserving or undeserving could not be a proper subject of inquiry ${ }^{28}$ in their period of old age. This made for a more inclusive and, since unworthy as well as worthy old people must be fed, clothed and housed, a more satisfactory remedial program.

In consequence an increasing number of countries adopted the contributory annuity plan. France, ${ }^{29}$ Luxemburg, ${ }^{30}$ Roumania, ${ }^{31}$ the Netherlands ${ }^{32}$ and Sweden $^{33}$ had enacted compulsory old-age insurance measures before the outbreak of the World War. Between 1918 and 1930 moreover, thirteen additional European ${ }^{34}$ countries, Great Britain among them, had taken a similar step as had several of the Latin American countries. There was also a series of special enactments for selected industrial groups. ${ }^{35}$ Practically all of the measures provided for invalidity as well as for old age. During this period only Canada, ${ }^{36}$ South Africa, ${ }^{37}$ Norway $^{38}$ and

${ }^{27}$ Compare Section 17 of Australia's act, supra note I9, with the "moral qualifications" clause in the New Zealand.Act, supra note I7. The Newfoundland Act, supra note 23, had no "moral qualification" clauses. For Great Britain's gradual release of the "moral qualification" clauses, see I \& 2 Geo. V, c. I6, $\$ 4$ (I9II); 9 \& Io Geo. V, c. 102, \$3 (I919). Also compare Denmark's qualification clause in her 1927 Statute, INt. LABor Office Legis. Series 1927, Denmark 2, \$2-13, with that included in her original act, and discussed supra, p. 177.

${ }^{23}$ But see Danish 1933 Invalidity Insurance Law, infra note 40.

${ }^{20}$ For an analysis, sce Bulletin du Ministere du Travail igio, p. 384 ; for translation, Int. Labor OFFICE, 5 BULL. (1910) $36 \mathrm{r}-375$.

${ }^{30}$ INT. Labor Office, 6 Bult. (I9II) cxxvi-cxxxvii. $\quad{ }^{31} 8 \mathrm{id}$. (I9I3) xxx-xxxv.

${ }^{33} 9 \mathrm{id}$. (I914) cxx. Operation of this act was deferred until I923. See INT. Labor Office, Legts. SERIES I923, Netherlands 6 . ${ }^{3}$ INT. Labor OfFice, 9 Bulz. (2914) 191-203.

${ }^{24}$ Austria (1925), Belgium (1924), Bulgaria (1924), Czechoslovakia (1924), Great Britain (1925), Greece (1924), Hungary (1929), Italy (rg19), Poland (1928); for commercial employees only, Portugal (I919), Spain (I919), Russia (1921), Yugoslavia (1922), Chile (1924), Argentina (I921) (operation suspended) (for citations to the foregoing laws and their chief amendments and description of their subject matter, see Armstrong, Insuring the Essentials (1932) App. Chart VIII).

\%Bolivia (1926) (bank employees); Brazil (192I) (railroad workers); Cuba (1923) (railroad workers), (1927) (maritime workers).

${ }^{87}$ Union of South Africa Stat. 1928, No. 22.

${ }^{3 a}$ Canada Stat. 1927, c. 156.

sa INT. Labor OfFICE, Leols. Series 1923, No. I. 
Uruguay ${ }^{39}$ had enacted gratuitous pension laws and that of Norway was and still is non-operative.

Since 1930 , interest in compulsory annuity provision has continued to gain momentum and a change in opinion is evident in even the pioneer gratuitous pension countries. Denmark, while still granting non-contributory old-age pensions, since I933 makes them available only to those who comply with the new rules compelling sickness and invalidity insurance. ${ }^{40}$

New Zealand in 1935 appointed a government departmental committee which has recently reported and recommended that New Zealand adopt a "National Compulsory Superannuation and Health Insurance" scheme.41 The suggested plan follows the conventional pattern. Under its terms wage earners and salaried employees up to a certain income level would be required to insure and participation on a voluntary basis would be open to better-paid employees and to farmers, merchants and professional men.

All of the old-age insurance schemes of general application, except those of Sweden, Belgium and Chile, and, to a very limited extent, Great Britain, ${ }^{42}$ confine their compulsory provisions to wage earners. This has been done for purely administrative reasons. Employers are used as collecting agencies for the government, through whom the insured workers are reached. The enforcement problems of the poll tax are involved in the attempt to compel contributions from self-employed persons whose need for old-age security is, of course, not to be differentiated from that of persons who are employed by others.

Sweden braved the administrative dangers of "popular" coverage and in her 1913 measure riequired the insurance of all persons between the ages of sixteen and sixtyfive unless they were working in an occupation for which old-age pensions were already required. Contributions or premiums varied directly with income and were payable to the tax-collecting agencies. Municipalities were held responsible for unpaid contributions and delinquencies brought serious problems to local authorities. Experience indicated an average of fifteen percent of unpaid premiums which rose as high as forty to fifty percent in certain industrial districts. This has caused serious questioning in Sweden of the advisability of her coverage arrangements. ${ }^{43}$

${ }^{\infty} 1 d$., Uruguay 2.

${ }^{2}$ By a law enacted in 1933, only those who insure against sickness and invalidity (and all physically able to gain membership in sickness funds were required thereafter to insure) or are unable, for physical reasons, to qualify for such insurance, are eligible for old-age pensions. The full cost of old-age pensions is still met out of the public funds and the same moral and "needs" qualifications are retained. Furthermore, these same qualifying provisions now also apply to the contributory invalidity insuranee pensions. For a full description of this hybrid scheme, see INT. IABOR OFFICE, 47 INDUSTRIAI AND LaBour IngormaTTON (I933) 278-9, 306-309.

is See 57 id., (1936) 17-20, for a summary of the plan proposed.

"Great Britain's scheme, since I928, has included certain manual workers who in legal theory are independent contractors, not employees. For purposes of insurance they are deemed employees of the persons for whom they perform personal services, i.e., the customers, and the latter have the responsibility of employers. This inclusion covers such workers as timber fellers, hay cutters, hedgers, brick makers, etc., who contract for "jobs." See 18 \& 19 Geo. V, c. 14, 5201 (1928).

"See Liedstrand, Social lnsurance in Sweden (1924) 9 INT. LABOR REv., 177, at 779 et seq. 
Belgium and Chile, in addition to requiring their wage earners to insure, included self-employed workers whose earnings approximated that of industrial workers. To what extent this additional coverage has been effective is not of record.

Great Britain's extension of compulsory coverage to manual independent contractors handled administratively through the device of treating their customers as employers, was attempted only after more than twenty-five years of social insurance experience, when a substantial degree of conformity with insurance obligations was normal. Thus managed, the additional inclusion presents no greater enforcement difficulties than are involved in the insurance of domestic servants in private homes.

Survey of the twenty-odd contributory annuity plans ${ }^{44}$ reveals considerable variation in detail but marked similarity in general pattern. Most systems limit the compulsion in the case at least of the non-manual workers, to persons earning less than a stipulated annual amount. This amount is set at a figure considered high enough to include all those persons who remain dependent upon their earnings throughout their lives. Almost without exception the insurance scheme is open on a voluntary basis to highly paid employees who are exempted from compulsory insurance and to independent workers, small merchants and other persons of moderate income. The majority now include both agricultural workers and domestics, although workers in these employments are still excepted in some countries which have recently set up their social insurance schemes. Special enforcement problems have caused a frequent deferring of the protection of farm labor and domestic service until the social insurance obligations have become normal accepted incidents of employment contracts.

In three-fourths of the schemes both employers and the insured workers ${ }^{45}$ contribute regular shares of the premium due and the state exchequer shares in the financing in most instances, by adding a supplement to the pensions produced by the premiums. Sixty-five is the most usual age at which annuities become payable, sixty and seventy being the minimum and maximum age limits set in any of the plans. ${ }^{46}$

The amount of annuity is consistently small even in the light of the standard and cost of living of the country. The pension is obviously intended to furnish only a minimum subsistence, and some supplementary income is clearly contemplated as normal. The pension varies in almost all of the systems ${ }^{47}$ with the wage level of the worker and with the length of his contribution period. A minimum amount, however, is usually included, which protects to a certain extent the man of very low earning capacity.

"For detailed information the reader is referred to Armstrong, Insuring the Essentrazs (1932) App. Chart VIII, where the coverage, financing, benefits, etc., of each act are set forth.

${ }^{25}$ The worker is not required to contribute in Spain, Holland and Russia. The employer contributes nothing in Sweden. The worker often does contribute both in Spain and Holland, and it is contemplated that he shall in order to get a substantial annuity as the amount otherwise is very small.

"Several of the schemes, however, set a lower age limit for women workers than for insured men.

"Great Britain is a conspicuous exception. Her contributory annuity, like all her social insurance benefits, is a flat rate for all insured workers, without regard to their wage level. 
The provision for invalidity is less generous in most cases than that made for old age. Even the usual definition of invalidity is a harsh one. Most of the schemes require that the manual worker suffer a reduction of earning capacity of two-thirds or more than two-thirds, although non-manuals are frequently allowed to qualify for an invalidity pension on permanent loss of earning capacity of more than fifty percent. The severity of the qualification clause for manuals is related to the everpresent fear, not wholly unjustified, that invalidity insurance will be imposed upon by older workers who are not really invalided but find it difficult to obtain employment in competition with younger men. If in administration of the insurance a liberal appraisal of the worker's physical disability is made where actual invalidity is present and strict compliance with the qualification clause is used only where imposition is believed to be present, the definition justifies itself. Obviously invalidity inšurance cannot remain solvent if used as a species of unemployment insurance.

Placing too high a retirement age, of course, compounds administrative difficulties in connection with invalidity insurance, as the worker who has reached "economic old age," i.e., the period when he can no longer hope to have regular work, yet cannot draw his annuity and so lacks regular income, will rapidly deteriorate physically.

Special "transitional provisions" directed at more adequate annuities for those workers who were past middle age when the insurance scheme began to function, than could be produced by their contributions, were included in all of the measures. This was done for the obvious reason that, due to the date of adoption of the system, the older workers were placed at great disadvantage as compared with the younger.

'Below is indicated a table, ${ }^{48}$ showing the relative size of old-age and invalidity pensions for eight selected countries. It has been assumed in preparing the table that the pensioner has a dependent wife of pensionable age, but no dependent children. In addition to showing the actual amount of pensions in the foreign currencies, to facilitate comparison by the American reader, the pension is stated in each case as a percentage of the laborer's wage in the country concerned.

It may be noted that the Dutch pension is a particularly small one. This is due to the fact that no worker's contribution is actually required. The worker contributes to the extent that he desires to add to this basic pension.

The most significant post-war enactment was that of Great Britain's contributory annuity plan in $1925,{ }^{49}$ after seventeen years' experience with gratuitous pensions for the "aged and deserving poor." A very important aspect of this shift lay in the fact that the gratuitous pension plan denuded of its "moral qualifications" clause was retained not just for the transitional period of launching the annuity program but as

${ }^{43}$ Adapted from a table in ArMstrong, Insuring thie Essentials (1932) 4 47.

49 'This added complete survivors' insurance as well as old-age insurance. See 15 \& 16 Geo. V, c. 70 (1925). 
Calculated Weekiy Old-Age and Invalidity Pensions for Various Countries in Relation to Weekly Wages in Those Countries*

\begin{tabular}{|c|c|c|c|c|c|c|c|c|}
\hline Country & Unit & $\begin{array}{l}\text { Old-Age } \\
\text { Pensiont } \\
\text { (Weekly) }\end{array}$ & $\begin{array}{c}\text { Invalidity } \\
\text { Persion at } \\
\text { Aze } 55 \\
\text { (Weekly) }\end{array}$ & $\begin{array}{c}\text { Invalidity } \\
\text { Pension at } \\
\text { Ase } 40 \\
\text { (Feekly) }\end{array}$ & $\left|\begin{array}{c}\text { Weekly } \\
\text { Whazes } \\
\text { Unskilled } \\
\text { Labor in } \\
\text { Engineering } \\
\text { Trades }\end{array}\right|$ & $\begin{array}{c}\text { Old-Age } \\
\text { Pension } \\
\text { As a } \\
\text { Percent } \\
\text { of Wages }\end{array}$ & $\begin{array}{c}\text { Invalidity } \\
\text { Pension at } \\
55 \text { as a } \\
\text { Percent } \\
\text { of Wages }\end{array}$ & $\begin{array}{l}\text { Inoalidity } \\
\text { Pension at } \\
40 \text { as } \\
\text { Percent } \\
\text { of Wag es }\end{array}$ \\
\hline $\begin{array}{l}\text { Belgium......... } \\
\text { Czechoslovakia.... } \\
\text { France........... } \\
\text { Germany......... } \\
\text { Great Britain..... }\end{array}$ & $\begin{array}{l}\text { francs....... } \\
\text { crowns...... } \\
\text { francs...... } \\
\text { marks....... } \\
\text { shillings and }\end{array}$ & $\begin{array}{l}61.5 \\
87.50 \\
72.00 \\
12.15\end{array}$ & $\begin{array}{c}74.04 \\
72.00 \\
10.62 \\
.\end{array}$ & $\begin{array}{r}35.85 \\
72.00 \\
8.02\end{array}$ & $\begin{array}{r}145.80 \\
170.26 \\
153.21 \\
34.89\end{array}$ & $\begin{array}{l}42.1 \\
51.4 \\
47.0 \\
34.8\end{array}$ & $\begin{array}{l}43.4 \\
47.0 \\
30.4\end{array}$ & $\begin{array}{l}31.6 \\
47.0 \\
23.0\end{array}$ \\
\hline $\begin{array}{l}\text { Hungary..... } \\
\text { Italy........ } \\
\text { Netherlands. }\end{array}$ & $\begin{array}{l}\text { pence..... } \\
\text { pengos....... } \\
\text { lire......... } \\
\text { florins....... }\end{array}$ & $\begin{array}{l}20 / 0 \\
13.16 \\
58.14 \\
6.12\end{array}$ & $\begin{array}{c}7 / 6 \\
10.99 \\
49.83 \\
5.43\end{array}$ & $\begin{array}{c}7 / 6 \\
7.74 \\
37.56 \\
4.50\end{array}$ & $\begin{array}{c}44 / 2 \\
23.52 \\
121.88 \\
25.31\end{array}$ & $\begin{array}{l}45.3 \\
56.2 \\
47.7 \\
24.2\end{array}$ & $\begin{array}{l}17.0 \\
47.0 \\
40.9 \\
21.5\end{array}$ & $\begin{array}{l}17.0 \\
32.9 \\
30.8 \\
17.8\end{array}$ \\
\hline
\end{tabular}

The pensions have been calculated for a worker whose average wage during the whole period involved is equal to or fall s within the same wage class as the average weekly wage paid to unskilled laborers in the engineering trades.

$f C a l c u l a t e d$ for a worker and his wife at the age at which the benefits begin.

a permanent supplement to the contributory scheme. This was in recognition of the fact that the contributory program could not guarantee the entire population an income in old age. In fact, while it would do so for the great majority of persons whose income came from their labor rather than from property, it would not completely cover even this group. This was due to the fact that for administrative reasons already mentioned, it only reached the workers who spent their lives as wage earners in the employ of others and thus offered no protection to persons who, while equally dependent upon earnings, were self-employed. ${ }^{50}$ Moreover it was accepted as inevitable that a certain proportion of persons from high income groups would, through business losses or unfortunate investments, come to financial grief in their old age.

The contributory annuity plan was set up and clearly designed to be the standard old-age security device which in time would carry the major load and the gratuitous pension program was retained to provide for the minor group who fell outside the annuity scheme and who arrived at old age without subsistence income.

It was arranged that the premiums charged for the contributory annuities which were divided between the insured workers and their employers should be gradually stepped up over a long period of time. ${ }^{51}$ They were calculated at an amount which, at their maximum, would, if placed at interest at four percent, furnish the promised

${ }^{50}$ See note 42 , supra.

51 For a full explanation of the technical basis of the scheme, including actuarial forecasts, etc., see (1926) 13 INT. LABOR REv. 36r-38r, 506-522. The continental schemes in contrast have been placed, at least in theory, chiefly upon a "reserve" or "accumulation" basis. It is generally believed, however, that contributions in all countries are concededly inadequate for straight "capitalization" of premiums. See in this connection, Transactions of 9TH INT. Cong. of Actuaries, Vol. III (1930) (papers on old age insurance in various countries). E.g., K. Lindner, actuarial adviser of the State Insurance Bank at Amsterdam, says (id. at p. 475) "It is a notable fact, that so far as I am aware, in state pension schemes no attempt has ever been made to provide capital sufficient to cover any future requirements."

Germany's reserves were completely wiped out during the inflation period 1921-1924. For ten years thereafter, the scheme was frankly upon a straight assessment basis. "Reformation," effective from r934, is directed at putting the scheme, as rapidly as economic conditions will permit, on a reserve basis. For 
annuities for the workers who contributed them. Instead, however, of placing them at interest, the government planned, while retaining a reserve plan on paper for guidance, to pay the current annuities out of current premiums. The government was pledged to supply in return for this, by future annual grant as needed, what was lost to the Pension Fund by not capitalizing the contributions.

The advantages of this technique are fiscal. It obviates the accumulation of large reserves with their attendant investment problems. It entails no sacrifice of safety as would a private venture proceeding on such a basis, since the social insurance program involves an entirely different situation. The private concern has no absolute assurance of a future. It may not be able to attract policy holders. The age distribution of the policy holders which it does secure is not assured. It must, to secure its ability to make good its promises to those who insure with it, build up out of the investment of the premiums, reserves from which the annuities can and will be paid. The social insurance program on the other hand has an assured future of constantly added policy holders who have no choice about insurance. Their age distribution is equally predictable and it will be "favorable" since they will be the workers of society. The future resources and obligations of the scheme thus can be forecast, and the stability of the government and its taxing power stand back of the government's promise to make good by future grant as needed what is lost by non-capitalization of the premiums.

The British program, in short, is based on a complete understanding of social insurance as distinguished from private commercial insurance, and Great Britain has adjusted a safe, orderly annuity scheme to what it deems to be the soundest principles of general government finance.

It should be remarked in making passing reference to the old-age assistance plans adopted in the United States during the late twenties, ${ }^{52}$ that these state laws differed in a vital respect from the gratuitous pension provisions of other countries. They all, without exception, granted assistance to the needy old person only when he did not have a spouse or children (or, in many cases, other listed relatives such as sisters and brothers) who were able to support him. The foreign measures, in contrast, judged the applicant on the basis of his own financial situation without forcing his dependence upon his children.

The American measures thus definitely were a mere variety of poor relief and the assistance grants did not deserve the term "pensions" which certain of the states have applied to them. Their chief contribution was that they marked a definite step away from the neglect of the aged which characterized the shameful almshouse era

a full discussion of technical basis of present scheme and projected plans, see $2 \mathrm{I}$ INT. LAvor Rev. (March, April, October, 1935) 398-418, 539-554, and 22 id. 515-522.

The French system is, professedly at least, dominantly a "reserve" rather than "pay-ass-you-go" scheme. Guarantee of a minimum pension, however, and confessedly inadequate premiums make a state subsidy implicit if pension claims are to be met. For complete explanation of the actuarial basis of the French scheme, see Mowbray, The New French Social Insurance Law, i7 Proceedings of the Casuarty Actuaruar SOCIETY (193I) $24 \mathrm{I}-263$.

For a graphic analysis of these laws, see 39 U. S. Montrily LABor Rev. 255; $4 \mathrm{I}$ id. 303. 
from which this country has so lately emerged. The efforts made to secure the passage of these measures, moreover, educated the citizenry both to the existence of a serious old-age dependency problem and to the need of systematic provision of old-age security other than enforced institutional care. ${ }^{53}$

In summary it may be stated that in the course of the half century that has elapsed since Germany launched the first compulsory annuity program for industrial workers, various methods of attacking the problem of old-age dependency have been tried. 'The two techniques for achieving old-age security which have received major attention are contributory annuities and gratuitous pensions for needy and deserving aged. Resting as they do upon different philosophical bases, for a long period these were deemed mutually exclusive remedial programs between which countries should choose. The gratuitous pension plan, for the "worthy poor," for twenty years or so attracted more interest perhaps than old-age insurance, voluntary or compulsory. ${ }^{54}$ Experience with such provision, however, convinced most countries that in practical operation it tended to become relief for the needy rather than' reward for the worthy and that, as such, it was both a more costly and a less satisfactory old-age security device than a contributory annuity program. The latter, by putting provision for old age on a business-like basis of steady building during working years of annuity rights in old age, removed pensions altogether from the undesirable sphere of poor relief. Since, moreover, the annuity was not conditioned upon "need," the worker derived the full advantage of any savings he was able to accumulate. ${ }^{56}$ Thus self-help was promoted, not discouraged. The contributions from the insured workers and their employers, which furnished the major part of the funds needed for the annuities, relieved the general treasury of substantial burden.

The limiting of compulsory insurance to wage earners, for persuasive administrative reasons has had almost universal approval and for similar reasons coverage of certain groups has been deferred in some cases and has been provided for in a special separate scheme in others. The undesirability of omitting from the scheme self-employed workers of earning capacity similar to that of the insured group has been universally recognized. Their voluntary participation in the annuity scheme has been encouraged and in one country of major importance, Great Britain, some of the manual self-employed now are included in the compulsory system by an ingenious administrative device. Lastly it has become increasingly apparent abroad that the supplementing of the contributory insurance arrangements, compulsory and voluntary, by a gratuitous pension plan to provide for those who arrive at old age without either private means or an annuity, is essential to a rounded-out program of old-age security.

\footnotetext{
For an excellent picture of this problem, see Rubinow, The QUEsT FOR SEcurity (1934) cs. XVIIIXXIII, inclusive. It should be noted that under Arizona's law, Stat. 1933, c. 34, the income and property of the spouse only-and not that of the children of the applicant-is pertinent.

"See id., c. XXIV, for an interesting comparison of "straight pensions" and "contributory annuities"; and see Armstrong, Insuring the Essenttals (1932) 43I-2.

It should be remarked, however, that the state subsidy is not paid to the pensioner of high income under the laws of Czechoslovakia, INT. LABor Office, Legis. Series 1928, Cz. 2, \$123 (4); Luxemburg. (non-manual workers), id., 1931, Lux. 2, $\$ 16$ (d); and Sweden, id., 1921, Swe. 2, 5 I4.
} 